\title{
Empirical Analysis of Factors Influencing Economic Growth Rate in Bangladesh
}

\author{
Fatema Jannat ${ }^{1}$, Mohammad Rubel Miah ${ }^{1}$, Mohammad Omar Faruk ${ }^{2}$, , Shafiqul Alam ${ }^{1}$ \\ ${ }^{1}$ Department of Business Administration, Noakhali Science and Technology University, Noakhali, Bangladesh \\ ${ }^{2}$ Department of Statistics, Noakhali Science and Technology University, Noakhali, Bangladesh
}

Email address:

omarfaruk.faruk396@gmail.com (M. O. Faruk)

${ }^{*}$ Corresponding author

\section{To cite this article:}

Fatema Jannat, Mohammad Rubel Miah, Mohammad Omar Faruk, Shafiqul Alam. Empirical Analysis of Factors Influencing Economic Growth Rate in Bangladesh. International Journal of Business and Economics Research. Vol. 9, No. 2, 2020, pp. 78-82.

doi: 10.11648/j.ijber.20200902.14

Received: January 12, 2020; Accepted: February 21, 2020; Published: March 10, 2020

\begin{abstract}
Economic growth rate plays an important role in the development of a country. Bangladesh has tremendous success to increase its economic growth rate and now it is known as the fastest-growing developing country in the world. This paper explores the important factors that influence the economic growth rate in Bangladesh. The data for the analysis is extracted from the United Nations Conference on Trade and Development from 2000 to 2015. For bivariate analysis, the correlation coefficient is measured and for multivariate analysis, multiple linear regression model is fitted. For the statistical analysis, the statistical software $\mathrm{R}$ program is used. The bivariate analysis shows that gross national income, export merchandise, import merchandise, foreign direct investment, population, remittance pay, remittance receive are correlated with the gross domestic product. Pearson's correlation between GDP and balance of payment, ICT import and ICT export is found to be very low. The factors which are moderately or highly correlated with the GPD have been used in the multivariate model. The most significant factors that influence the gross domestic product is gross national income and remittance received. The study also found that export merchandise and import merchandise have a significant impact on the economic growth in Bangladesh.
\end{abstract}

Keywords: GDP, FDI, Remittance, Economic Growth Rate, Import, Export

\section{Introduction}

Economic growth is considered as one of the most important parameters for the development of a country. The market-based economy of Bangladesh is one of the fastest growing economies in the world. Bangladesh is classified among the next eleven emerging market middle income economies and a frontier market [1]. Bangladesh is among the three fastest growing economies in the world, according to the International Monetary Fund (IMF). It also ranked Bangladesh is the $39^{\text {th }}$ largest in the world in nominal terms, and 29th largest by purchasing power parity with a GDP of US\$ 314.656 billion [2]. Bangladesh's GDP per capita reached 1827.000 USD in June 2019, compared with 1675.000 USD in June 2018 [2]. The data reached an alltime high of 1827.000 USD in June 2019 and a record low of
88.691 in June 1960 [3]. GDP annual growth rate in Bangladesh averaged 5.84 percent from 1994 until 2018, reaching an all time high of 7.90 percent in 2018 and a record low of 4.08 percent in 1994 [4]. Hence, GDP growth of Bangladesh has been 6 percent and above in the past decade or so with increasing exports, imports and remittance. Nowadays, most of the emerging countries' crucial objectives are ensuring economic growth and sustainable development. Potential increase in output level is necessary for all developing countries to meet various challenges like easing the balance of payments problem, embracing wave of global integration to resolve domestic issues like unemployment $\&$ inflation. To improve performance in economic growth requires positive changes in the level of production of goods and services. This process is made possible by various factors \& their interaction with each other. In an economy like developing countries, export 
growth is considered as a key determinant of production \& employment growth. GDP's rapid growth due to sound financial control \& regulations has contributed to its growth. The importance of population is crucial because it has significant impacts on the development and growth process of a country. The trained and efficient labor force has made a notable contribution to GDP growth in Bangladesh. Remittance and foreign direct investment are yet to rise significantly. Bangladesh received $\$ 15.5$ billion in remittance last year, more than 15 percent year-on-year, according to the World Bank [5]. Remittance is one of the key drivers of the country's economic growth, accounting for 5.4 percent of the gross domestic product in the year. Therefore, Bangladesh's per capita gross national income (GNI) jumped more than 9 percent to $\$ 1909$ last fiscal year from $\$ 1,751$ a year ago, showed provisional official figure [5]."Bangladesh continues to be one of the fastest growing economies in the world. Robust growth in industrial and service sectors, supported by higher public and private consumption, have boosted growth," said World Bank Bangladesh Country Director Robert J Saum [5]. To sustain this progress, this paper attempts to identify the most important factors that influence the GDP growth rate in Bangladesh, GDP is taken as dependent variable and Foreign Direct Investment, Gross National Income, population, ICT export, ICT import, Balance of Payment, Remittance pay, Remittance received, Export, Import variables are taken as independent variables. Though numerous studies have identified different factors, present study has used correlation coefficient \& multivariate regression analysis to assess the variables that affects the economic growth of the country. To reach a final conclusion to determine the factors influencing GDP growth rate in Bangladesh, an extensive literature survey is conducted. Finally, the findings, conclusion and policy recommendations have been presented in this study.

\section{Literature Review}

Accelerating the rate of economic growth of a nation poses an essential issue in economic debate. Several researches have been conducted on various macroeconomic variables to show the relationship among them. An attempt has been made to review the recent available literature on economic growth seeking to determine and assess factors that may influence the economy and how they act on it.

A series of studies have focused to determine the relationship between remittance and economic growth. From micro and macro point of view, remittance constitutes an important source of foreign exchange for the developing countries. overseas remittances achieving a favorable balance of payments and creating a new resources base for the country [6]. Another study found that remittances have a long-term impact on the receiving economy only if these flows are invested in long -run technology or used for capital investment [7]. On the other hand, remittances exercise a weak positive effect on long-term macroeconomic growth by using dynamic panel estimation [8]. The study found that remittance income of Tonga falls with an appreciation of the currency of the country. Likewise, the empirical research found that personal characteristics like, education level, being a male and type of employment have significant positive impact on remittance inflow to the home country [9].

Foreign Direct Investment (FDI) is also considered in most empirical studies as one of the key factors with a positive impact on economic growth. The effects of foreign direct investment on economic growth in developing countries and found positive relationship between FDI and economic growth [10]. FDI generally has a positive impact on economic growth in developing countries as it helps to build physical capital, create employment opportunities, develop productive capacity and enhance skills of local labor. The study found that the increase in FDI inflows in South Asia were associated with a many-fold increase in the investment by national investors, suggesting that there exist linkage effects between FDI and GDP [11]. The analysis on a panel of 84 countries, highlights in most cases a positive impact of FDI on economic growth, but also remarks that in countries with the technological gap, FDI has a significant negative impact on economic growth [12]. The determinants of FDI and its effect on economic growth in developing countries are studied and results revealed that FDI has an important effect on economic growth of third world countries by creating bridge between the gap of domestic savings and investment and familiarizing the up to date technology and management skill from developed countries [13]. Moreover, FDI is found to have a positive and significant impact on growth when host countries have better level of initial GDP and human capital. Hence, FDI has significantly positive impacts on economic growth and domestic investments by evaluating the prospects and challenges of FDI and its impact on economy in Bangladesh [14]. In terms of especially developing countries, the relationship between foreign trade and economic growth continues to be an issue keeping its validity in both theoretical literature and empirical literature [15].

On the other hand, many economists considered foreign trade as the "Engine of Growth" because it facilitates the specialization in the production of goods and services. Economic theories suggest that export earnings reduce the dependence on foreign aid, augment the base of industrialization, increases foreign exchange earnings, create employment opportunities, helps in transformation of the economic structure etc. Trade policy and economic growth for Bangladesh by using co-integration and multivariate Granger Causality test and results showed a long-run relationship among the three variables as well as feedback effects between exports and output growth and also between imports and output growth in the short-run [16]. However, a group of Asian economies achieved high rates of economic growth and did so via a process that involves rapid growth of exports rather than substitution of domestic production for imports [17]. By examining the process of Bangladesh's trade liberalization and its impact on the growth, structure of exports, imports, GDP and other macroeconomic variables with particular emphasis on export. Trade liberalization has a 
positive impact on the growth, that is, both anti-export bias reduction and import-GDP ratio have significantly impacted on exports in the long run [18].

In the literature, inflation is one of the macroeconomic factors considered most often as having a negative impact directly or indirectly on growth [19]. Inflation can lead to uncertainty about the future profitability of investment projects especially when high inflation is also associated with increased price variability. Inflation may also reduce a country's international competitiveness, by making its exports relatively more expensive, thus impacting on the balance of payments. Although the authors acknowledge that the negative effect refers to the situations when inflation is high and they find even situations where on the background of the existence of inflation some countries managed to record economic growth. In addition, analyzing $5 \mathrm{CEE}$ countries, during 1993-2007, this study finds a positive impact of inflation, attributed to measures taken by the governments of these countries to maintain it at a low level [20].

Poor basic infrastructures are a barrier to ICT adoption in DCs. To properly adopt and use ICTs, basic infrastructure requirements of electricity, trained technical workers, and communication networks, as well as commitment from the government and other policy makers, should be put in place [21].

To calculate the national income of a country, one of the most widely used method is gross national income, or GNI. It is the total domestic and foreign output claimed by residents of a country, consisting of gross domestic product (GDP), plus factor incomes earned by foreign residents, minus income earned in the domestic economy by nonresidents [22]. GNI is a strong indicator of the standard of living of an average citizen in the country through dividing country's income by its population. By comparing a country's GDP and GNI, we can determine how much foreign aid or foreign labor a country receives. If a country's GNI is much higher than their GDP, it means they receive a lot of foreign aid, whereas if their GDP is much higher than their GNI, it means that non-citizens make up a large portion of the country's production [23].

The effect of population on economic development is studied by applying ordinary least squares methodology inferred that economic growth is positively affected by population growth [24]. But the main problem is the management of problems associated with huge population i.e. newly supplied labor force, providing them job opportunities and other basic facilities for life become a great challenge for the policy makers and government. The comparative trend of population growth determinants have been analyzed between developing countries (Bangladesh, Ethiopia, Indonesia, Mexico and Nigeria) and developed nations (Germany and United States) and this trend analysis showed that fertility rate, crude death rate, birth rate, mortality rate, and life expectancy are the major determinants of rapid population growth rate while youth dependency ratio of young people below the age 15 has also been attributed as one of the major causes of population growth and growth threat in developing countries [25]. Moreover, the higher population in many developing countries is a hindrance to economic growth and development due to lack of other productive resources [26]. However, other empirical studies demonstrated that an increase in labor is a factor favoring economic growth [27].

\section{Methodology}

The data for this analysis has been extracted from the UNCTAD (United Nations Conference on Trade and Development) from 2000 to 2015. The objective of this research work is to examine the factors which influence the GDP growth rate in Bangladesh. In this study, we have used annual GDP as a dependent variable to analyze the economic growth rate in Bangladesh. Currently, most of the countries in the world GDP is widely accepted as an indicator as to the measure of economic growth (Bogdon Florin Filip, 2015). On the other hand, we considered ten independent variables FDI, GNI, BOP, population, remittance pay, remittance receive, export merchandise, ICT import, ICT export and import merchandise to assess the factors which influence the GDP growth rate in Bangladesh. Correlation coefficients have been measured to observe the relationship between GDP and the factors. For multivariate analysis, a multiple linear regression model has been developed. Our proposed regression model is as follows:

$$
\begin{gathered}
\mathrm{GDP}=\mathrm{FDI}+\mathrm{GNI}+\text { Population }+ \text { Remittance Pay }+ \\
\text { Remittance Receive + Export Merchandise + Import } \\
\text { Merchandise. }
\end{gathered}
$$

For bivariate analysis, MS Excel has been used and for multivariate analysis, the $\mathrm{R}$ program is used.

\section{Result and Discussion}

\subsection{Bivariate Analysis}

From table 1 we see that GDP and BOP are weakly negatively $(-0.22)$ related. Weak and negative relation also found in ICT export and ICT import with the response variable GDP. This means that BOP, ICT export, ICT import have no significant influence over GDP. On the other hand, all the remaining variables are highly positively correlated with GPD, which means that with the increase in the value of these variables the GDP of Bangladesh will also increase. The correlation between GDP and ExportMerchandise is 0.98 , which means that there is a highly positive relationship between GDP and ExportMerchandise. The correlation between GDP and Import Merchandise is 0.98, which means that there is a highly positive relationship between GDP and ImportMerchandise. The highly positive relationship is also found in the variables FDI, GNI, Population, Remittance Pay and Remittance Receive. The variables which found negative and weak relationship with the dependent variable have been excluded from the model for multivariate analysis. 
Table 1. Correlation table of GDP and independent variables

\begin{tabular}{|c|c|c|c|c|c|c|c|c|c|c|}
\hline & BOP & $\begin{array}{l}\text { Export } \\
\text { Merchandise }\end{array}$ & $\begin{array}{l}\text { Import } \\
\text { Merchandise }\end{array}$ & FDI & GNI & $\begin{array}{l}\text { ICT } \\
\text { Export }\end{array}$ & $\begin{array}{l}\text { ICT } \\
\text { import }\end{array}$ & Population & $\begin{array}{l}\text { Remittance } \\
\text { Pay }\end{array}$ & $\begin{array}{l}\text { Remittance } \\
\text { Receive }\end{array}$ \\
\hline GDP & -0.23 & 0.98 & 0.98 & 0.99 & 0.99 & -0.15 & -0.27 & 0.94 & 0.95 & 0.89 \\
\hline
\end{tabular}

\subsection{Multivariate Analysis:}

To observe the impact of independent variables considered in this analysis over GDP a multiple linear regression model has been constructed. The regression model we considered here is as follows:

$\mathrm{GDP}=\mathrm{FDI}+\mathrm{GNI}+$ Population + Remittance Pay + Remittance Receive + Export Merchandise + Import Merchandise.

Where GDP $=$ Gross Domestic Product

GNI $=$ Gross National Income

FDI $=$ Foreign Direct Investment

Table 2. Multiple linear regression model.

\begin{tabular}{|c|c|c|c|c|c|c|}
\hline & Estimate & Std.Error & t value & p-value & Lower 95\% & Upper 95\% \\
\hline (Intercept) & 4888.04 & 9830.19 & 0.50 & 0.63 & -17014.99 & 26791.08 \\
\hline FDI & 0.51 & 0.36 & 1.43 & 0.185 & -0.29 & 1.30 \\
\hline Population & -0.03 & 0.08 & -0.45 & 0.66 & -0.20 & 0.13 \\
\hline Remittance Pay & 24.18 & 41.28 & 0.59 & 0.57 & -67.81 & 116.17 \\
\hline Remittance Receive & -0.59 & 0.15 & -4.03 & $0.0024 * *$ & -0.91 & -0.26 \\
\hline Export Merchandise & -0.41 & 0.15 & -2.65 & $0.0242 *$ & -0.75 & -0.07 \\
\hline Import Merchandise & 0.29 & 0.11 & 2.57 & $0.0280 *$ & 0.04 & 0.55 \\
\hline
\end{tabular}

Sig.codes: 0 ‘***’ 0.001 '**’ 0.01 '*’ 0.05 ‘’ 0.1 ' 1

Residual standard error: 534.2 on 10 degrees of freedom

Multiple R-squared: 1, Adjusted R-squared: 0.9999

F-statistic: $3.421 \mathrm{e}+04$ on 7 and $10 \mathrm{DF}$, p-value: $<2.2 \mathrm{e}-16$

Table 2 reveals that GNI is more significant ( $p$-value: 2.09e-11, CI: 0.89 and 1.02) factor which influence the GDP growth rate in Bangladesh. The regression coefficient 0.95 indicates that for a unit change in GNI the GDP will grow about 0.95 . The variable population and remittance pay is seems to have no significant impact on GDP since their pvalue is greater than the level of significance (0.05). From table 2 we found that remittance receive has significant influence (p-value: 0.0024 and CI: -0.91 and -0.26) on GDP. From table 2 we also found that the p-value for export merchandise and import merchandise is 0.02 and 0.03 respectively which are less than the level of significance $(0.05)$ and are significant in GDP growth rate in Bangladesh. From table 2 we observe that the p-value for FDI is 0.185 which is greater than the level of significance alpha (0.05), this means that the effect of FDI on GDP is insignificant. FDI has no significant impact on GDP may be due to complicated bureaucracy, the absence of autonomous regulatory bodies, political unrest, inconsistent policy implication, lack of effective cooperation by the Board of Investment (BOI) etc.

\section{Conclusion}

The key objective of this study is to find out the important factors which influence the economic growth in Bangladesh. Ten independent variables have been considered to check the significant impact on GDP for the period of 2000-2015. The correlation coefficient is measured for bivariate analysis and multiple linear regression is performed as multivariate analysis. Remittance receive, Export merchandise, Import merchandise and GNI are highly significant factors that influence the economic growth of Bangladesh. On the other hand Population, Remittance pay and FDI have no significant impact on the GDP. FDI is considered to be a significant factor for a country for economic growth but our study reveals that it is insignificant for the economic growth of Bangladesh. Further study is needed on FDI for its best implementation in Bangladesh. The government of Bangladesh should take the necessary steps to create trained and efficient manpower for its population.

\section{References}

[1] Wikipedia. Economy of Bangladesh. Retrieved from https://en.wikipedia.org/wiki/Economy_of_Bangladesh.

[2] The Daily Stat. IMF. Retrieved from https://www.thedailystar.net

[3] The Central Eastside Industrial District. (1960-2019). CEIC Data. Retrieved from https://www.ceicdata.com

[4] Trading Economy. (2019). Retrieved from https://tradingeconomics.com 
[5] The Daily Stat. 2019, Retrieved from https://www.thedailystar.net

[6] Ali, S. A., 1981. "An Analysis of the Institute of Home Remittance by Bangladeshi Workers Abroad on the National Economy in Labour Migration from Bangladesh to the Middle East". The World Bank Staff Working Paper 454, Washington, D.C.

[7] Mundaca G. (2005). Can remittances enhance economic growth? The role of financial markets development. Mimeo, University of Oslo.

[8] Catrinescu, N., Leon-Ledesma, M., Piracha, M. \& Quillin, B. (2009). Remittances, institutions, and economic growth. World Development, 37 (1): 81-92.

[9] Emmanuel, N. O., William, F. M., Gladys, A., Denis, Y. N. (2012), Microeconomic determinants of migrant remittances to Nigerian household, Economics Bulletin, 32 (4), 34253438 .

[10] Agosin, M. R. and R. Mayer, 2000, "Foreign investment in developing countries: Does it crowd in domestic investment?" UNCTAD Discussion Paper 146, Geneva.

[11] Agrawal, P. (2000). Economic impact of foreign direct investment in South Asia. India and the WTO, 117.

[12] Li, X., and Liu, X. 2005. Foreign direct investment and economic growth: An increasingly endogenous relationship. World Development 33 (3): 393-407. doi: 10.1016/j.worlddev.2004.11.001.

[13] Mottaleb, Khondoker Abdul, 2007. "Determinants of Foreign Direct Investment and Its Impact on Economic Growth in Developing Countries," MPRA Paper 9457, University Library of Munich, Germany.

[14] Rahman, A. (2012). Foreign Direct Investment in Bangladesh, Prospects and Challenges and Its Impact on Economy.

[15] Çetinkaya, M and Erdogan, S (2010), "Var Analysis of the Relation between GDP, Import and Export: Turkey Case." International Research Journal of Finance and Economics, Vol. 55, pp. 135-145.

[16] Chaudhary, M. A., Shirazi, N. S., \&Choudhary, N. A. S. (2007). Trade policy and economic growth in Bangladesh: A revisit. Pakistan Economic and Social Review, 45 (1), 1-26.
[17] Krugman, P. R. and Obstfeld, M. (2009), "Export-oriented Industrialization: The East Asian miracle," in: International Economics: Theory and Policy, 8th ed., Pearson: Addison Wesley, Boston.

[18] Hossain, M. A., \&Alauddin, M. (2005). Trade liberalization in Bangladesh: the process and its impact on macro variables particularly export expansion. The Journal of Developing Areas, 127-150.

[19] Fischer, S. (1993) The Role of Macroeconomic Factors in Growth, Journal of Monetary Economics no. 32. M.I.T. Cambridge, USA, pp. 485-512

[20] Ristanovic, V., Macroeconomic Determinant Of Economic Growth And World Economic-financial Crisis, Facta Universitatis (Economics and Organization) Vol. 7, No 1, 2010, pp. $17-33$

[21] Davis, F. D., Bagozzi, R., and Warshaw, P. R. (1989) "User Acceptance of Computer Technology: A Comparison of Two Theoretical Models," Management Science (35:8), pp. 9821003 .

[22] Todaro, M. P., \& Smith, S. C. (2011). Economic Development 11. Addison-Wesley, Pearson, ISBN, 10, 0-13.

[23] MasterClass, 2019, Retrieve from: https://www.masterclass.com

[24] Adewole, A. O. (2012). Effect of population on economic development in Nigeria: A quantitative assessment. International Journal of Physical and Social Sciences, 2 (5), 1-14.

[25] Atanda, A. A., Aminu, S. B. and Alimi, O. Y. (2012), "The Role of Population on Economic Growth and Development: Evidence from Developing Countries", Online at MPRA Paper No. 37966.

[26] Agarwal, S. H. U. B. H. I. (2014). Impact of India's population growth on economic development'. Paripex Indian journal of research, 3 (5).

[27] Edwin, D, Shajehan, H. (2001) Determinants of Economic Growth (Panel Data Approach). Economics Department Reserve Bank of Fiji Working Paper 01/04. 